\title{
Las armas a cambio de la libertad. Los esclavos en la guerra de independencia de Venezuela (1812-1835)
}

\author{
Ana Vergara* \\ UNIVERSIDAD SIMÓN BOLÍVAR
}

Tanto los republicanos, como los defensores del poder monárquico no preveían el impacto y la importancia de la participación esclava durante la guerra de independencia venezolana. Su inicial movilización a favor de la Justa Causa del Rey fue una de las razones de la destrucción de las dos primeras repúblicas. Su participación induce a Bolívar y demás dirigentes republicanos a reformular el programa independentista criollo; el cual no incluía, hasta el momento, un cuestionamiento del sistema esclavista, en tanto que eran beneficiarios directos del mismo y la institución formaba parte fundamental del sistema económico en que se desenvolvían. Este artículo trata abordar su participación en el conflicto a través de las experiencias relatadas por nueve esclavos en sus respectivas peticiones de libertad.

(Independencia, esclavitud y conscripción)

$\mathrm{L}$

a noche del 22 de marzo de 1813, el doctor Bartolomé Rus, vecino de Maracay, población de la provincia de Venezuela, cura de la localidad. El propósito: que deleitase a su familia con el toque de su violín, instrumento que el otrora siervo manejaba con cierta habilidad. Entre los intermedios musicales, uno de los presentes le preguntó, con indiferencia, sobre el estado de cosas en Puerto Cabello después de los últimos acontecimientos de la revuelta insurgente, refiriéndose a la primera revolución de Caracas que tuvo lugar entre 1810 y 1812 . El negro expresó que lo más conveniente era no decir nada; los invitados hicieron silencio, pero luego le incitaron 
a que relatara lo que sabía, prometiendo a cambio sigilo y confianza. Sin más estimulo, el negro contó que en su reciente viaje a Norteamérica se había enterado de los robos hechos por los españoles a los criollos y "con entera satisfacción” -como declararían al día siguiente los presentes de aquella velada ante el justicia mayor del pueblo- les habló de los preparativos de lo que aparentaba ser un levantamiento patriota en diversos parajes de la provincia de Venezuela, el cual terminaría, afortunadamente para él, con la rendición de las plazas de Maracaibo y Puerto Cabello. ${ }^{1}$

Desconocemos si las afirmaciones del recién liberado esclavo eran ciertas o más bien se trataba de un invento con el cual buscaba obtener mayor atención de la que lograba con su virtuosismo en el violín. El propósito de este trabajo es mostrar cómo a los esclavos no les fue ajena la guerra a pesar de encontrarse en el nivel más inferior de la sociedad estamental colonial de la provincia de Venezuela; por el contrario, ésta los incluyó abruptamente y en la medida que necesitó de su fuerza al tiempo que rechazaba y, sobre todo, temía su influencia. ${ }^{2}$

No obstante, la abundancia de relatos similares que existen en los archivos históricos venezolanos, los estudios sobre la participación esclava en la revolución independentista son escasos en la historiografía nacional. Los existentes en la actualidad, de mayor vigencia y difusión, son esencialmente laudatorios, poéticos, con poco sentido crítico y esencialmente sustentados en el paradigma de

${ }^{1}$ Archivo General de la Nación, Archivo Aragua, tomo LxxiII, folio 96. Este expediente criminal no va mas allá de una denuncia, no se supo de la suerte que corrió el liberto.

${ }^{2}$ Para comienzos del siglo xIX el sistema esclavista ya no aportaba lo suficiente a la economía de la provincia como en el siglo xviII. La población esclava representaba sólo, en la provincia de Caracas, 26 por ciento del total del individuos, de una zona que comprendía los fértiles valles de Aragua y del Tuy, no obstante, la institución se mantenía estable en sus principios. El concepto de negritud continuaba siendo un adjetivo indivisible a la condición del esclavo, y como tal conllevaba asociado una serie de calificativos relativos a la existencia de esta población al margen de aquella sociedad estratificada estamentalmente, donde cada quien poseía una función económica y política de acuerdo a la tenencia o no del exclusivo valor de honor. El esclavo no formaba parte de esta estructura, era un segmento agregado, que ocupaba el lugar más bajo de la escala social colonial. En gran medida el desprecio hacia las demás castas era medido por la presencia en su origen o en su pasado más remoto, de esta raza considerada torpe y envilecida; negritud se traducía al mismo tiempo en bastardía. 
la historiografía patria. Se observa en ellos cómo la figura heroica de Simón Bolívar ensombrece su real y verdadera participación. En estos trabajos, los esclavos tienen vida, surgen y participan cuando Bolívar los toma en cuenta en sus proclamas libertarias de 1816; de la misma manera, desaparecen de la escena cuando el Libertador deja de mencionarlos hasta 1821 . Otro de los resabios de la historia patria es el silencio que se ha guardado ante la participación de los esclavos durante el periodo 1812-1816, omitiendo hechos como las revueltas esclavas de Barlovento de 1812 que invocaban al rey Fernando VII y el grueso de soldados negros que se incorporaron voluntariamente al mando de jefes realistas como José Tomas Boves y demás caudillos fieles a la monarquía. En virtud de esta carencia historiográfica, este trabajo se orienta a mostrar el proceso independentista a través de las peticiones de libertad promovidas por seis esclavos que militaron tanto en las filas armadas de los republicanos como en las de los seguidores de la causa monárquica.

\section{Ramón Piñero: SOldado ESClaVo DEFENSOR}

DE LA JUSTA CAUSA DEL REY

"Yo he servido con mucho amor y fidelidad a mi Rey, y no quiero perder la gracia que su soberana clemencia concede a los que como yo han defendido sus derechos con el arma en la mano". ${ }^{3}$ Con estas palabras inició el esclavo Ramón Pinero su petición de libertad en 1815, después de servir dos años en el ejército del rey. De acuerdo con su testimonio, la guerra llegó a él en septiembre de 1813 cuando laboraba en el hato San Diego perteneciente a su señor, en los llanos centrales de Calabozo. Ese día, los insurgentes llegaron a dicho lugar $\mathrm{y}$, sin mediar explicaciones, tomaron preso a su amo, don Juan de Rojas, y lo colocaron en la cárcel de esa ciudad.

En agosto de este año, Simón Bolívar restableció el segundo intento de gobierno republicano, después de completar su exitosa

3 "Ramón Piñero, esclavo del doctor don Juan de Rojas pide su libertad por haber luchado en los ejércitos reales”. Caracas, 1815, Academia Nacional de la Historia, 1815 op, exp. 5 . folio 1 . 
Campaña Admirable con la toma de Caracas en agosto de 1813. Unos meses antes -en junio de 1813- Bolívar proclamó el Decreto de guerra a muerte en la ciudad de Trujillo, en el cual se estableció la persecución y exterminio de todo aquel identificado con la causa realista o que fuese indiferente con el proyecto republicano. La repentina detención de Juan Rojas evidenció que se encontraba comprendido en los principios de esta proclama. Frente a este escenario, Piñero y otro esclavo llamado Miguel, tomaron la deliberación de enlistarse en los ejércitos comandados por José Tomás Boves, impulsados por el agravio cometido ante la persona de su dueño, y atraídos por la oferta de libertad si tomaban las armas a favor de la causa del rey.

En ese entonces, la leva de esclavos y el ofrecimiento de libertad que le acompañó, era un procedimiento de reciente práctica, que surgió como necesidad por la coyuntura bélica. Antes de que la revolución alterara la cotidianidad colonial, los esclavos sólo podían lograr su libertad si la compraban, se las otorgaba un amo o si escapaban al cimarronaje. ${ }^{4} \mathrm{La}$ toma de las armas fue considerada como un deber que no merecía otro premio que la gratitud, pero con el inicio de la guerra, los oficiales de ambos bandos necesitaban engrosar sus filas y el otorgamiento de la libertad era el factor clave que impulsó a los esclavos a incorporarse a las fuerzas en pugna. Con la llegada del oficial realista Domingo de Monteverde a Tierra Firme en 1812, éste no emitió bando que ofreciera la libertad a aquellos esclavos que tomaran las armas en nombre de Fernando VII; no obstante, diversas denuncias de propietarios dan fe de lo

${ }^{4}$ De acuerdo a las Siete Partidas de Alfonso X, un esclavo alcanzaba su libertad, primeramente por las buenas acciones al servicio de su amo o de su rey, o de denuncias de acciones que pudiesen perjudicar la integridad física o del honor de sus dueńos, como por ejemplo acciones conspirativas. Otra forma, era si un esclavo se casaba con persona libre, tenía la posibilidad de serlo siempre y cuando el amo lo desease, pero una vez aplicada esta normativa a la realidad americana, donde el sistema esclavista llegó a ser una institución más importante que en la España medieval, se derogó por medio de una Real Cédula en 1527. Igualmente, esta ley estipulaba liberar a un esclavo a través de la última voluntad del amo en las cláusulas de su testamento, o en una declaratoria hecha en su lecho de muerte. En América estos caminos se multiplicaron, cada caso podía tener una razón distinta que podía ser considerada por un tribunal dependiendo de cada caso. 
contrario. ${ }^{5}$ Testimonios de la época aseguran que el jefe realista asturiano José Tomás Boves empleó ampliamente este recurso, y fue uno de los motivos de la conformación de su gran ejército.

Ramón Piñero, animado por la oferta de obtener su libertad, entró en acción en La Sabana de Mosquiteros frente a los batallones comandados por el oficial patriota Vicente Campo Elías el 14 de octubre de 1813, allí tuvo su primer encuentro armado y una de las muchas derrotas que le provocaron las heridas y padecimientos que mellaron más tarde su salud. Los 2,500 hombres enlistados por José Tomás Boves sufrieron una derrota contundente, además de las bajas propias de la contienda. La mortandad fue mayor cuando los prisioneros fieles a la causa del rey fueron ajusticiados por órdenes de Campo Elías, inclusive aquellos que no eran españoles y que no se encontraban comprendidos en el Decreto de guerra a muerte. Ramón, entre tanto, emprendió la retirada con los demás sobrevivientes en dirección al poblado de Guayabal, ubicado a las riberas del río Apure, lugar establecido por los monárquicos como punto de encuentro en caso de que la ofensiva no resultase favorable.

Tras la primera derrota, transcurrieron dos activos meses en la vida de Ramón. Mientras la temporada de lluvia inundó los llanos en Guayabal, Boves preparó su ejército con nuevas estrategias y arsenal fabricado con los materiales que la región y sus pobladores se vieron forzados a entregar. Paulatinamente se iban incorporando nuevos soldados al ejército. Fortalecidos con el ganado y municiones

${ }^{5}$ Una correspondencia emitida por los vecinos del puerto de La Guaira el 4 de agosto de 1812, nos muestra ciertos vestigios de que el canario Monteverde llegó a emplear esta formula para captar combatientes. Dicho comunicado concernía a una denuncia en contra del oficial realista Julián Poncho, quien frente a su división de Curiepe iba reuniendo en su trayecto por los pueblos de la costa de Naiguata a esclavos de las haciendas, en dirección a la capital con el objeto de presentarse como soldados frente al general don Domingo de Monteverde, para ser así premiados con su libertad. Los dueños advierten al general que esos, sus esclavos, no habían realizado poco o ningún servicio a la causa de su amado soberano Fernando VII, éstos se habían incorporado a esa división después de vencidos los insurgentes. Por lo demás, más allá de ser soldados, eran vándalos que habían cometido atropello y maltrato a sus dueños al sentirse aupados por las promesas de libertad, por lo tanto no eran merecedores de esa gracia que otorgaba el general a esclavos destacados en servicio. Archivo General de la Nación, Gobernación y Capitanía General, Correspondencia, tomo cCxx, año 1812, exp. 75, p. 100. 
que arribaron de Guayana, Boves emprendió la segunda campaña por los llanos. Avanzó con la intención de apoderarse de Calabozo, el paso de San Marcos hacia esta ciudad lo encontró pobremente guarnecido por el espańol y republicano Manuel Aldao, quien contó con unos pocos soldados que en pocas horas perecieron bajo la arremetida de la caballería realista. Despejado el paso el 8 de diciembre de 1813, Calabozo cayó en manos de Boves y de sus efectivos, quienes cumplieron al pie de la letra las órdenes impartidas en Guayabal, todo blanco de la recién conquistada ciudad fue pasado a cuchillo. Desconocemos si Piñero fue uno de esos verdugos, obviamente su petición de libertad tres años más tarde no incluyó una confesión de este tipo, menos cuando el juez que decidiría su causa era el gobernador y capitán general Salvador de Moxó, funcionario destinado por Pablo Morillo, para atender las denuncias de soldados realistas que hicieron una guerra de colores empleando el estandarte de la justa causa del rey.

Con la contundente victoria sobre los insurgentes en La Puerta el 15 de junio de 1814, el ejército de Boves se dividió en dos, uno se dirigió a Caracas y otro, comandado por él mismo, tomó Valencia. Por la declaración de Piñero, él estuvo en este último grupo, y el 16 de julio de 1814 entró a Caracas. Para ese momento, en la modesta ciudad capital, que viajeros de distintas procedencias alabaron por su belleza, reinaba la desolación. Además de los daños aún presentes del devastador terremoto de 1812 y los casi cuatro años de guerra, a la nueva fisonomía de la ciudad se agregó la soledad que dejaron sus pobladores tras su huida en dirección a oriente inducidos por el temor de ser las nuevas víctimas de las legendarias degollinas promovidas por el otrora comerciante asturiano y sus seguidores. De acuerdo con la declaración que brindó Piñero, permaneció poco tiempo en la capital y regresó con Boves a Calabozo, donde se planearía la persecución de los republicanos.

En ese momento, tras 10 meses de marchas y batallas: Piñero cayó enfermo en los hospitales de Villa de Calabozo, un año permaneció enfermo en ese lugar. Apenas sintió una mejoría, en el mes de noviembre se dirigió a la capital para exigir la libertad que le habían ofrecido a cambio de sus servicios. Desde el 11 de mayo de 
1815, Caracas estaba bajo la dirección del brigadier español Pablo Morillo y la ofensiva republicana había sido sofocada en gran parte del territorio, colocando al movimiento insurgente en su más mínima expresión.

Boves murió el 5 de diciembre en Úrica, y con su muerte quedaron sin efecto los ofrecimientos de libertad sin credencial escrita. El nuevo régimen vio con suspicacia las solicitudes de libertad adelantadas por este tipo de soldados, quienes frente a las autoridades realistas eran los sospechosos de la llamada guerra de colores que caracterizó a la guerra de independencia el ańo de 1814. No obstante, la participación y colaboración de estos contingentes no pudo ser obviada, y las Instrucciones de Fernando VII encomendadas a Morillo para la recuperación de la posesiones ultramarinas estableció una serie de condiciones en torno a esta materia. Se otorgó la libertad sólo a aquellos soldados que comprobaron sus servicios por medio de informes emitidos por sus superiores, los cuales debieron destacar las acciones militares en las que participaron, las labores que desempeñaron y su disposición a dichas tareas, finalmente debían continuar sirviendo en sus unidades el tiempo que durase la guerra. Por ello, una vez revisada la solicitud de Piñero por el asesor general y el entonces capitán general Salvador Moxó, éstos concluyeron apegándose a los principios de esa disposición

deben quedar libres los esclavos que estén, con las armas en la mano indemnizándose a los dueńos el valor de ellos del real erario, pero con calidad de que queden sirviendo de soldados en el ejército; por esta misma disposición opino que Ramón Piñero, aunque son ciertas y recomendables los servicios militares que alega no esta comprendido en aquella gracia, por haberse separado de la milicia, sin que hasta ahora conste causa o impedimento legitimo para este. ${ }^{6}$

Conocido este fallo desfavorable, Piñero apeló afirmando que sí era merecedor de la gracia otorgada por el rey, pues defendió con amor y fidelidad la causa; tanto, que su precaria salud era resultado de

6 “Ramón Piñero, esclavo del doctor don Juan de Rojas pide su libertad...”, folio 2. 
ello. Solicitó ser reconocido por un facultativo, para que certificase que su "curación es algo larga, y para otro temperamento que no sea tan destemplado, como este". 7

Piñero permaneció varios meses en Caracas pero el clima frío no favoreció su recuperación, y más allá del clima curativo de Calabozo, su deseo era regresar libre a su hogar. Inmediatamente el tribunal autorizó la revisión a cargo del protomédico Joseph Joaquín Hernández, quien observó que el entullecimiento de las coyunturas de Ramón no tenía curación, por lo que lo diagnosticó como un hombre baldado e inútil.

Al diagnóstico lo respaldó el testimonio de su amo Juan de Rojas, quien no se opuso a la petición -en espera de que el real erario reintegre el precio de su esclavo- aseguró que "este esclavo ha sido siempre sano y las enfermedades que ha tenido han sido adquiridas en la campaña por las humedades, trabajos, vigilias y (ilegible) que son consecuentemente, pues antes de entrar en el servicio, fue siempre sano, de buenas costumbres, y eficaz". ${ }^{8}$ Sin mayor oposición de su amo, a Ramón Pinero se le declaró persona libre de esclavitud y servidumbre el 23 de diciembre de 1815 por sus comprobados servicios a los derechos del rey en estas provincias.

Hubo otro esclavo que solicitó su libertad por servir a la justa causa del rey, pero a diferencia de Ramón que fue un soldado, éste fue un oficial: ostentaba el grado de jefe de división de los ejércitos del rey.

\section{JuAN José LEDESMA: JeFE DE DIVISIÓN DEL EJÉRCITO DE SU MAJESTAD}

Juan José Ledesma, aspiró a su libertad en 1815 por su servicio militar en los ejércitos de su majestad, donde obtuvo el grado de jefe de división durante el mando de José Tomás Boves en 1813 y 1814. Juan José, oriundo de la población de San Rafael de Orituco, en las planicies de Guarico, perteneció a los bienes de don Pedro Ledesma, reconocido patriota desde los inicios de la independencia. En 1813,

${ }^{7}$ Ibidem, folio 4.

${ }^{8}$ Ibidem, folio 4 vto. 
restablecida la república después de la culminación de la Campaña Admirable por Simón Bolívar y el éxito de la Campaña de Oriente por el general Santiago Mariño, desde los llanos se conformaron fuerzas opuestas al nuevo gobierno, frente a ello los ejércitos patriotas reforzaron sus filas y pertrechos con la colaboración de sus más fieles y acaudalados seguidores, quienes aportaron dinero y esclavos aptos para el servicio. Don Pedro, el amo de Juan José siguió este ejemplo y colocó a su esclavo bajo las órdenes del republicano José Manuel El Torres. Junto a la división comandada por este oficial sirvió un tiempo, pero no tardó en abandonar la causa que le obligaron defender, y voluntariamente se incorporó en el mes de octubre del año de 1813 en la tropa fidelista comandado por Manuel Ramírez, para seguir la sagrada causa del rey en defensa de sus justos derechos contra los insurgentes de esta provincia. ${ }^{9}$ En ese momento el ejército realista, a diferencia de las comandancias patriotas, sí contempló la libertad como forma de pago para aquellos esclavos que brindaran destacadas acciones: quizás esto último fue decisivo en la determinación de Juan José de enlistarse en el ejército realista.

De acuerdo con la declaración de su superior Manuel Ramírez, el esclavo tuvo destacadas acciones que le valieron el ascenso a jefe de división; su labor específica consistió en la recolección y venta de ganado, mulas, yeguas y burros que se vendieron para adquirir ropas y pertrechos para las distintas divisiones, o que simplemente se emplearon para alimento de las tropas movilizadas. De esta forma, el esclavo Juan José se convirtió en hábil practicante de la forma de exacción más empleada por las milicias que comandó Boves, mecanismo controvertido que dejó en total ruina a las haciendas y hatos ganaderos sin importar la facción que defendieran sus propietarios.

En julio de 1815, cuando Juan José hizo la petición de libertad, cumplió con todos los requisitos para alcanzarla: contó con la certificación de su superior directo Manuel Ramírez, para el momento de la solicitud continuaba en servicio, mientras que su amo era per-

9 "Juan José Ledezma, esclavo de don Pedro Ledezma, solicita su libertad por haber militado en los ejércitos realistas". San Rafael de Orituco, 1815, Academia Nacional de la Historia, 1815 LM exp. 1, folio 1. 
seguido y sus bienes estaban en poder de la junta de secuestros. Como no tuvo dinero para cancelar las costas de los procedimientos legales, aconsejó que éstos fueran pagados de los bienes embargados a su amo cuando el tribunal lo determinase. Lo único que empañó su solicitud fue su inicial militancia en el ejército patriota, lo cual puso en duda su lealtad. Sin embargo, él señaló que desde el instante que desertó de las filas insurgentes arriesgó su propia existencia y mayor demostración de lealtad al rey era imposible.

Desconocemos si Juan José obtuvo su libertad, pues el expediente se encuentra incompleto. Posiblemente logró carta de libertad, pues cumplió con todos los requisitos y fue un soldado activo para el momento de su acreditación. Sin embargo, un posible atenuante en esta decisión pudo estar sujeto a los nuevos dictámenes de las autoridades coloniales, empeñadas en restituir el orden, tal como menciona Germán Carrera Damas en su trabajo La crisis de la sociedad colonial. ${ }^{10}$ Con la llegada a Venezuela de Pablo Morillo se procedió a destituir de sus cargos a estos hombres pertenecientes a bajos estamentos y que habían alcanzado grados militares durante el mando de Boves. Dicha situación provocó el descontento entre las milicias y desencadenó deserciones masivas, eliminó la base popular del ejército del rey. En tal sentido, un número limitado de esclavos alistados lograron su libertad por este mecanismo en el ejército real, de igual forma un grupo lo logró por medio de sus servicios a los ejércitos republicanos, aunque en este caso no siempre fue así.

\section{LA REPÚBLICA CRIOLLA ESCLAVISTA}

Para el momento que fueron expulsadas las autoridades coloniales tras la instalación de La Junta Conservadora de los Derechos de Fernando VII el 19 de abril 1810, los esclavos continuaron realizando las mismas actividades que se les impuso siglos atrás. En el nuevo gobierno no existió un cuestionamiento del sistema esclavista porque éste era parte de la dinámica social en la que se desenvolvieron.

${ }^{10}$ German Carrera Damas, La crisis de la sociedad colonial, Caracas, Imprenta Municipal, 1976, 101. 
Las esclavas de casa continuaron caminando detrás de sus señoras llevando en sus manos la alfombra donde éstas se posaban durante los servicios religiosos. Aquellos que laboraron en las plantaciones se continuaron despertando con el llamado de sus caporales a tempranas horas de la madrugada para iniciar sus extenuantes faenas.

Esta rutina poco se alteró cuando el general Francisco Miranda, atendiendo a la gran deserción de soldados en 1812, dispuso la incorporación de mil esclavos al ejército ofreciéndoles la libertad sólo a aquellos que militasen 4 años y tuviesen destacadas acciones militares. ${ }^{11}$ La resolución ocasionó críticas y reservas que no provenían exclusivamente de los partidarios realistas, también los republicanos que vieron en la medida un factor desestabilizador. ${ }^{12}$ De esta forma, las dos primeras repúblicas concluyeron sin incorporar en su programa de gobierno la emancipación de los esclavos. Esta situación se modificó después de 1815 como lo veremos a continuación.

\section{Los bUenos SERVICIOS PRESTAdos POR ANASTASio Romero A FAVOR DE LA REPÚBLICA}

Después de peregrinar por diversos puertos caribeños tras la caída del segundo intento de gobierno republicano en 1814, Simón Bolívar, en compañía de otros patriotas como Gregor MacGregor, Manuel Piar y Santiago Mariño, partió de Los Cayos de San Luis

11 "Acto sobre conscripción de los esclavos de 19 de junio de 1812". Archivo del General Miranda (Campaña de Venezuela, prisión y muerte del General Miranda: 1811-1816) Documentos oficiales de 1811 a 1812 y correspondencia de 1812 a 1816, tomo XXIV, La Habana, Editorial Lex, 1950, 573.

${ }^{12}$ Miguel José Sanz -Secretario de Estado, Guerra y Marina durante el mandato de Miranda en 1812- celebró la decisión del Generalísimo, en correspondencia de 4 de julio de 1812, pues se apartaba a los esclavos de los llamamientos realistas, pero opinó que ésta se debió hacer "hasta un grado que no cause temores, retirarse nuestros labradores á empujar la agricultura, que debe servir de cimiento al comercio". Otros como Francisco Paúl - combatiente bajo las órdenes del general Miranda- se mostró menos satisfecho sobre la disposición, quien aseguró que "Con motivo de la ley general sobre los esclavos, se han desolado las haciendas. Aquellos con la esperanza de su libertad las abandonan y vienen á presentarse al gobierno en donde son admitidos generalmente sin distinción de edades, robustez, ni tamaño". Para esta correspondencia véase Archivo del General Miranda, op. cit., t. XXIV, pp. 55-311. 
en Haití para dirigir varios encuentros navales en la isla de Margarita. De esta isla Bolívar partió a Carúpano donde emitió el 2 de junio de 1816 el Decreto Sobre libertad de los esclavos a los habitantes de Río Caribe, Carúpano y Cariaco, ${ }^{13}$ en el que se le ofreció la libertad y ciudadanía a los esclavos capacitados para el enlistamiento inmediato, es decir, hombres en edades comprendidas entre los 14 y 60 ańos de edad. Esta proclama es reconocida como una iniciativa propuesta por Alejandro Petión a Simón Bolívar como condición para la ayuda financiera que el presidente de la primera nación americana edificada sobre una exitosa revuelta esclava en 1791 estaba dispuesto a brindar. ${ }^{14}$

Cartas de Bolívar dirigidas a Petión, mencionaron el poco alcance de estos ofrecimientos en las esclavitudes, de igual manera lo señaló posteriormente José de Austria en su Bosquejo de la historia militar de Venezuela,${ }^{15}$ quien describió el recibimiento de estos decretos en la población con frialdad, asegurando además que la presencia esclava en las filas patriotas era un evento excepcional, y que esta supuesta indiferencia continuó para 1818 con la ratificación del ofrecimiento de libertad en los decretos dirigidos a los habitantes de los Valles de Aragua el 11 de marzo, a los de La Victoria el 13 del mismo mes, y el día siguiente a los pobladores de los Valles del Tuy. Sin embargo, el brigadier inglés James Hackett, quien partió de Inglaterra en 1817 para reforzar las fuerzas patriotas sudamericanas, hizo referencia a la importante presencia de esclavos y pardos en las filas patriotas. ${ }^{16}$

Posiblemente no hubo una adhesión masiva de esclavos, si se compara con las descripciones de la composición de las milicias de Boves, pero el reclutamiento esclavo voluntario no fue un evento extraño en las filas patriotas, así lo evidencian las peticiones de liber-

13 "Proclama a los habitantes de Río Caribe, Carúpano y Cariaco de junio de 1816". Simón Bolívar, Obras completas, t. viII, México, Editorial Cumbre, 1976, 197.

${ }^{14}$ Paul Verna, Petión y Bolivar, Caracas, Ediciones de la Presidencia de la Republica, 1980, 169.

${ }^{15}$ José de Austria, Bosquejo de la historia militar de Venezuela, vol. II, Caracas, Academia Nacional de la Historia, 1960, 448.

${ }^{16}$ James Hackett y Charles Brown, Narraciones de dos expedicionarios británicos de la independencia, Caracas, Instituto Nacional de Hipódromos, 1966, 62. 
tad de esclavos realizadas después de consolidado el proyecto republicano. Éste es el caso del esclavo Anastasio Romero, quien reclamó 10 años después de sus servicios la libertad que le ofrecieron a cambio de la toma indefinida de las armas.

El 10 de enero de 1826, el esclavo Anastasio Sosa se dirigió al intendente departamental de la ciudad de Caracas con el propósito de que sus servicios bajo las banderas republicanas fueran reconocidos a fin de obtener carta de libertad. De acuerdo con su relato, llegó a la capital de manera clandestina desde la hacienda de su amo Domingo Sosa ubicada en Choroní, de allí pasó a San Sebastián de los Reyes y posteriormente a Turmero en búsqueda de los testimonios de sus antiguos superiores, Juan José Liendo y La Rea y Francisco de Paula Alcántara. Ambos reconocidos oficiales del ejército patriota que ostentaron la Orden de Libertadores de los Ejércitos de Colombia, conocieron de manera detallada las acciones en las que intervino Anastasio y la herida que recibió en una de esas campañas; por ello, ante el pedimento verbal realizado por el esclavo el 1 de marzo de 1825, no dudaron en asentar por escrito sus buenos servicios.

Anastasio se incorporó al ejército en 1816 después de ver desfilar por las estrechas calles de Choroní a los seiscientos sobrevivientes patriotas del combate de Los Aguacates llevado a cabo el 14 de julio de 1816. El general de división escocés Gregor Macgregor y el coronel Carlos Soublette encabezaron esta retirada, y a su paso trataron de reunir tropas ratificando el decreto de libertad emitido por el Libertador a su llegada a Carúpano en el mes de junio. Anastasio, seducido por esta propuesta, se enlistó inmediatamente y partió de Choroní bajo las órdenes del comandante del "batallón Barlovento" Francisco Piñango. Bajo su dirección participó en las cruentas acciones del 2 de agosto en Quebrada Honda, donde se logró repeler al coronel realista Juan Nepomuceno Quero y sus quinientos hombres. Un mes más tarde, el 6 de septiembre, cuando Anastasio estaba peleando en oriente en la batalla de Los Alacranes, allí recibió un balazo en la pierna izquierda, la cual fue asistida de forma exitosa en el hospital que se instaló en el convento de la ciudad de Barcelona. Veintiún días después de haber sido herido, Anastasio retomó las armas al lado de sus antiguos compañeros de la compañía barloven- 
to en la batalla de El Juncal, en ese momento bajo la dirección del general de división Manuel Piar, quien dos días antes tomó el control de los batallones ahí asentados. Después de la derrota de Francisco Tomás Morales, continuó la reforma del nuevo ejército republicano, y Anastasio fue trasladado al batallón Orinoco o Río Claro y bajo las órdenes de Piar peleó en las acciones previas a la toma definitiva de Guayana en 1817. El 16 de marzo de 1818, Anastasio sirvió en los ejércitos dirigidos por Simón Bolívar en la batalla de Boca Chica o Seme contra las unidades conducidas por Pablo Morillo, donde la derrota provocó la dispersión de gran parte de los efectivos republicanos sobrevivientes. Anastasio, acorralado por el enemigo en las cercanías del pueblo de San Mateo, no le quedó otra alternativa que enrumbarse a su pueblo de Choroní, donde de acuerdo a su testimonio, fue reincorporado de nuevo por su señor Domingo Sosa. En un principio no pudo acreditar sus servicios hechos a la república, pues aún gobernaba la monarquía y admitir su militancia lo convertiría en reo de alto crimen; más tarde, cuando los republicanos se establecen definitivamente en el poder, la sujeción y potestad de su amo impidió cualquier intento de acreditación.

Cuando Domingo Sosa, dueño de Anastasio, se enteró de la causa iniciada por su esclavo, contó a los tribunales otra historia completamente distinta. Primeramente, aseguró que no se oponía a que su esclavo fuera declarado persona libre de servidumbre como premio de sus distinguidos servicios a la patria, siempre y cuando el Estado indemnice su valor como lo exigía La Resolución de 14 de octubre de 1821 sobre los esclavos que sirvieron a las armas republicanas. Dicha resolución, sancionada por el Congreso General de Colombia, emanó de una consulta hecha por el vicepresidente de Cundinamarca sobre el dilema de qué hacer con los esclavos que tomaron las armas y la forma de indemnización a sus propietarios.

El asunto lo resolvió el Congreso declarando que los esclavos debían ser aceptados en las filas bajo los pactos y condiciones que decidiera el gobierno en cada circunstancia. En ningún apartado de esta decisión se mencionó de forma expresa la libertad como retribución a los esclavos por sus servicios, pero la norma era precisa al aclarar la situación de los propietarios ante esta situación: debieron 
ser indemnizados y con preferencia de los fondos de manumisión de la república. Sosa, conocedor de la ley, quiso el valor de su esclavo; no obstante, su reclamo no terminó allí, aseveró que los fundamentos con que apoyó Anastasio su solicitud eran falsos.

Primeramente, el esclavo mintió sobre la manera en la que recaló en su hogar, pues en su declaración el esclavo aseveró que él lo incorporó a su propiedad en 1818, cuando la verdad era que se encontraba en la isla de San Tomas en calidad de exiliado desde 1814, en todo caso fue su esposa quien le brindó refugio y no sujeción. Según dice Sosa en su alegato

La acogida que le franqueó mi mujer, en semejante circunstancias, fue una exposición manifiesta respecto a toda mi familia, por repuntarse el gobierno español por un criminal o reo de muerte, la que sin duda sufrieron todos los dispersos que fueron descubiertos, y por consiguiente sobre estar desmentido su aserto por hallarme yo ausente en el tiempo a que se refiere, debía tributar las gracias a mi casa, que lo salvó y libertó su vida. ${ }^{17}$

En pocas palabras, Anastasio era un esclavo mentiroso que en lugar de agradecer el riesgo de su familia al protegerlo mientras era perseguido por el enemigo, su respuesta fue la ingratitud.

Agregó que Anastasio se encontraba en su hacienda de Choroní por su propia voluntad, ya que su mujer e hijos eran sus esclavos. Tanto es así, que desde ocho meses atrás se encontraba en la capital, donde trabajó por su cuenta, provecho y utilidad propia con lo que desmiente la supuesta oposición a la acreditación de sus servicios. Si Anastasio no lo hizo, era porque no había querido.

Ante esta declaración, el esclavo no emitió escrito alguno que desmintiera las afirmaciones de su amo y permaneció a su servicio hasta que arribó la sentencia del intendente interino. El dictamen estableció que el servicio de Anastasio fue con anterioridad a la ley de 14 de octubre de 1821, por lo que su solicitud no emanaba de

17 "Anastasio Romero, esclavo del señor Domingo Sosa, que se le declare libre en virtud de haber servido en los ejércitos de la República”. Caracas, 1825, Academia Nacional de la Historia, Caja 19 1825, exp. 4. 
ella; no obstante, consideró que el valor del esclavo sí debía salir de los fondos de manumisión después de que se realizara el justiprecio. Anastasio tenía 48 ańos, y un esclavo de su edad alcanzaba un valor de 230 pesos, pero "la quebradura que padece en la ingle derecha" 18 le rebajaba el precio a la mitad, por lo que Domingo Sosa recibió un valor total de 115 pesos. De esta manera, Anastasio quedó libre en Caracas, mientras su mujer e hijos siguieron siendo esclavos de Domingo Sosa en Choroní.

Las vicisitudes padecidas por Anastasio fueron totalmente distintas al de otro esclavo soldado llamado José Ambrosio, quien a diferencia de su familia sólo tuvo que sacrificar un nombre.

\section{José Ambrosio Hernández:}

\section{EL ESCLAVO CON APELLIDO DE HOMBRE LIBRE}

En mayo de 1828, llegó a la oficina de la jefatura general en Caracas un oficio procedente de la comisaría del puerto de La Guaira, dicha notificación solicitaba la comprobación del testimonio ofrecido por uno de sus reos que había sido apresado por sospecha de ser uno de tantos esclavos fugitivos que, protegiéndose del desorden de la guerra, privaron a sus amos de sus servicios. Luis Ambrosio Surruarregui no ocultó su antigua condición de esclavo, de la cual, afirmó, fue librado mucho tiempo atrás cuando su difunto amo le otorgó carta de libertad que extravió durante las tropelías de la guerra. Relatos como éstos no eran extraños a los oídos de las autoridades que lidiaron con la inmensa responsabilidad de reorganizar el sistema esclavista. Sin embargo, la declaración de su antigua militancia en la marina republicana hizo su relato inusual y ameritó inmediata comprobación.

En el mes de junio, el jefe policial general de la capital ordenó el traslado del nominado esclavo José Ambrosio Surruarregui, con el propósito de comprobar los servicios que supuestamente lo hacían libre. En ese momento, el trecho que divide a Caracas de La Guaira fue uno más de los tantos caminos que recorrió José Ambrosio des-

${ }^{18}$ Ibidem, f. 2. 
de que abandonó las riberas del Orinoco, en su Angostura natal al sur de Venezuela.

En 1811, cuando Caracas declaró la independencia, la provincia de Guayana permaneció fiel a la monarquía, caso contrario a las zonas septentrionales de la provincia que cargaron con el mayor peso del conflicto. Desde su fundación por las misiones de capuchinos, sus bastas extensiones de tierras sirvieron para la cría de ganado, y en menor cuantía para el cultivo. Por ello, la presencia esclava fue modesta, encargada en gran parte del servicio doméstico y artesanal, distinta a la población esclava de los valles centrales, destinada a la economía de plantación.

En este ambiente vivió José Ambrosio, quien fue propiedad del vizcaíno Luis Surruarregui. Como era costumbre, desde el día de su nacimiento recibió el llamativo apellido del que años más tarde renegó. 1817 fue el año que los Surruarregui y los demás habitantes de la provincia experimentaron los devastadores trastornos de la guerra; la ciudad, que sirvió de leal financista a la causa del rey y de zona de resguardo a los realistas perseguidos, conoció los estragos del asedio militar republicano.

Desde mayo de 1815, las fuerzas realistas asentadas en la ciudad vencieron varias embestidas patriotas en sus propias puertas, pero esto no disminuyó el impulso de los rebeldes, quienes, orientados por Manuel Piar, planificaron la arremetida definitiva que se prolongó por siete largos y tortuosos meses. Las líneas de abastecimiento de alimento fueron cortadas y los civiles acudieron a medidas desesperadas para suplir sus carencias, pero cuando la situación se hizo insostenible éstos huyeron por río logrando sólo un desenlace fatal. Uno de esos tantos hombres que recurrieron al exilio fue Luis Surruarregui quien, antes de partir dejó en total libertad a su esclavo José Ambrosio. Para los dueños de esclavos era preferible convertir a sus siervos en hombres libres responsables de su propia suerte, ya que cargar con ellos representaba un peso al momento de huir, un esclavo era una boca más que alimentar, o un espacio que ocupar en una embarcación.

Mientras su amo se enrumbó a su destino final en la isla de Martinica, José Ambrosio se dirigió a enlistarse voluntariamente a los 
ejércitos republicanos recién establecidos en Angostura. Al momento que se le tomaron los datos de su filiación y el comandante le dio a conocer las penas y ordenanzas que implicaba su nueva militancia, fue ingresado a la marina con el nombre de José Ambrosio Hernández. Con este apellido apareció en todos los listados de las embarcaciones que abordó en los distintos puertos necesitados del auxilio patriota.

Su primera experiencia como marinero se limitó a la protección del río Orinoco; posteriormente, de este sitio partió a los demás puertos que la causa republicana tomaba para sí. Recién llegado al puerto de La Guaira, siguiendo las órdenes de su comandante José María García, se embarcó en compañía de otros marineros a la isla de Margarita con la delicada labor de trasladar el correo. Esta actuación y positiva disposición le valió el reconocimiento de sus superiores, quienes años más tarde recordaron con facilidad sus buenos servicios.

Tres meses después de la victoria republicana en Carabobo, el 5 de octubre de 1821, José Ambrosio se embarcó en La Guaira en la polacra Constantinopla con destino a Nueva Granada, como parte de las últimas tropas que se incorporaron al asedio establecido por el almirante José Prudencio Padilla al gobernador de Cartagena de Indias, brigadier Torres y Velasco. Desconocemos si José Ambrosio llegó a tiempo a Cartagena para ser partícipe del cerco, ya que 5 días más tarde la resistencia de la ciudad se rindió tras haber soportado un año y tres meses del bloqueo iniciado el 14 de julio de ese año. De la recién conquistada Cartagena, Ambrosio fue trasladado de nuevo a La Guaira en una embarcación de la cual no supo precisar nombre, si La Voladora o Libertador, una vez allá se incorporó a las milicias que se organizaron en el puerto bajo la mirada del capitán Matías Padrón. Tres años más tarde, el 8 de noviembre de 1823, estaba presente en la toma de Puerto Cabello, el último bastión de los realistas en Venezuela.

Finalizada gran parte de las contiendas bélicas, encontró en el puerto de La Guaira su punto de retorno, y el lugar donde trató de reconstruir su vida como caletero tomando por hecho la libertad que le había dado inicialmente su amo y la cual quedó ratificada por 
su participación en la reciente guerra de independencia. Cinco años más tarde las autoridades de La Guaira dudaron de sus servicios prestados a la república, y lo colocaron como propiedad del Estado al servicio del hospital militar hasta que las autoridades de la capital ordenaran su traslado para dar inicio a la comprobación judicial de las historias que el considerado esclavo profirió.

A Surruarregui le cuesta acreditar su libertad, pues, como él explicó, la condición de marinero no le permitió tener contacto con gente de tierra firme, mucho más cuando el recorrido de las distintas embarcaciones en las que sirvió llegaron a puertos tan lejanos del extinto virreinato de Nueva Granada. No obstante, José Ambrosio seguro de sus servicios, solicitó la declaración de Matías Padrón, quien, además de ostentar el título de capitán de fragata de la armada de Colombia para 1829, era comandante de Marina y capitán del puerto de La Guaira. De igual manera pidió testimonio de Francisco Avendaño, coronel de los ejércitos de Colombia, y de Simeón Gómez, compañero marinero de José Ambrosio durante sus servicios. Ellos ratificaron la presencia del esclavo en los lugares y campañas por él señaladas y agregaron, además, otros servicios omitidos por el propio José Ambrosio en su declaración. Éstos resaltaron su espontánea disposición a la causa de la patria; no obstante, ninguno lo reconoció con el nombre de José Ambrosio Surruarregui, sino como José Ambrosio Hernández, tal como aparece registrado en las listas de las milicias marinas asentadas en el puerto de La Guaira.

Ante esta interrogante, José Ambrosio explicó en su declaración final el por qué de esta confusión, aseguró que una vez que su amo le otorgó la libertad en Angostura tomó el apellido de su padrino de bautismo, quien era un hombre libre, para así despojarse del apellido impuesto en servidumbre. De igual manera afirmó que pudo contar con más testimonios de sus reconocidos servicios en la marina, pero como él mismo aseguró

si mi desvalimiento y miseria no fuera un obstáculo poderoso para ocurrir al Comandante Beluche en Puerto Cabello, al Sr. comandante García en Margarita y a otros jefes en otros puertos importantes antes, pero los tres testimonios producidos son muy respetables y suficientes por manifestar 
la verdad de mi exposición y la justicia con que reclamo contra la servidumbre en que indebidamente me han constituido por haber ganado mi libertad en la peligrosa carrera de las armas y con servicios prestados a la patria en los días en que le eran muy apreciable útiles y aún necesarios. ${ }^{19}$

Conforme con los testimonios brindados por los superiores de José Ambrosio Hernández, el tribunal consideró indiscutible el goce de su libertad, tal y como lo prescribió el decreto de 1816 que ofreció la libertad a los esclavos que tomasen las armas en defensa del gobierno, pero para gozar de forma plena este derecho debió volver a sentar plaza como soldado por el tiempo que determinara la ley hasta que presentara el retiro del ejército que le correspondía por el dilatado tiempo de su militancia. Un año tardó en comprobar sus servicios, y doce días después del fallo favorable a su solicitud, José Ambrosio pidió copia de la sentencia para que le sirviese como carta de libertad, previendo que no volvieran a dudar de su naturaleza de hombre libre y lo redujesen de nuevo injustamente a la condición de esclavo.

José Ambrosio se involucró en la guerra cinco años después de iniciada, pero esclavos como Joseph Malpica la experimentaron desde el primer día.

\section{TRES REPÚBLICAS, UN ESCLAVO}

"Sr. suplico se me admita y dispense estos mis malos borrones en este papel pues la indigencia a que estoy expuesto me es intolerable soportar" ${ }^{20}$ Con estas líneas, seguidas de una firma alejada de los preciosismos propios de los escribanos, finalizó la exposición del una vez soldado y también esclavo Joseph de Jesús Malpica el 9 de febrero de 1827. A diferencia de otras peticiones de libertad, ésta no estuvo dirigida a un tribunal menor o a una junta de manumisión

19 "Expediente seguido por José Ambrosio Surruarregui, reclamando su libertad por haber servido a las tropas de la República”. Caracas, 1829, Academia Nacional de la Historia, 1829 LRST, exp. 6.

20 "José de Jesús Malpica, esclavo de los herederos de Melchor Canivel, sobre su libertad”, Caracas, 1827, Academia Nacional de la Historia, 1827 CMPR, exp. 2, folio 1. 
cantonal: el señor a quien Malpica le pidió excusas por sus errores, no es otro que el entonces Presidente y Libertador Simón Bolívar, a quien tuvo oportunidad de servir en el fatídico ańo de 1814.

Joseph de Jesús Malpica fue uno de los miembros de la guarnición que acompañó a Bolívar cuando se embarcó en Cumaná con el propósito de convencer a José Bianchi que retornara las riquezas que se le habían confiado en La Guaira. En ese entonces, Bolívar y Mariño fueron desconocidos como jefes del ejército por José Félix Ribas y Manuel Piar; Joseph de Jesús, después de ver partir a Bolívar, retornó a Cariaco al mando de los nuevos oficiales para defender la república.

Trece años después de ese encuentro, le pidió al libertador de las dos republicas hermanas que sus servicios sean reconocidos, servicios que no sólo se limitaron al año de 1814, sino que su militancia fue fiel durante la primera, segunda y tercera instalación de la república, hasta asegurarse el suelo patrio. En su exposición recordó la primera batalla a la que asistió bajo mando republicano, lo rememoró con precisión porque se llevó a cabo un día de San Pedro, es decir, un 29 de junio de $1812 .{ }^{21}$ Sumó filas en el batallón número quince comandado por un mayor apellidado Camacho. Para ese momento los ejércitos de la primera república actuaron defendiendo las pocas plazas que conservaban ante el avance de los realistas comandados por Domingo Monteverde, quien desde su entrada por Coro desde las Antillas unos meses atrás controló a su paso los poblados insurgentes. El enfrentamiento de ese 29 de junio era el segundo combate por la ciudad de La Victoria, y durante el mismo el generalísimo Francisco de Miranda logró rechazar el ataque sorpresa del enemigo. Sin embargo, la sensación de triunfo duró muy poco, un mes más tarde Miranda capituló ante el canario.

Joseph de Jesús volvió al servicio patriota cuando los republicanos alcanzaron el poder por segunda vez, y allí permaneció hasta

${ }^{21}$ Esta referencia es importante, primeramente nos demuestra la apreciación del tiempo en la provincia de Venezuela para el siglo xix que se ajustaba al santoral y a sus respectivas festividades religiosas. Por otro lado, las festividades de San Juan y San Pedro contaron con amplias manifestaciones entre las poblaciones esclavas negras de la provincia, como lo demuestran las cofradías fundadas bajo sus advocaciones. 
que las huestes de José Tomás Boves reconquistaron el territorio en nombre de Fernando VII. Cuando la república estableció su centro político en los márgenes del río Orinoco en la ciudad de Angostura, Joseph de Jesús ya era parte del batallón Orinoco, con el cual llegó a defender la causa patriota en Cumaná en el castillo de San Antonio. Posteriormente, en una fecha que no precisó, cayó preso en las bóvedas del puerto de La Guaira, ante la mirada indiferente de quien posteriormente lo solicitó como su esclavo. Después de concluidas las acciones militares se inició el retorno de los soldados a la vida civil, Joseph de Jesús hizo lo propio y se empleó en el oficio de caletero en el puerto de La Guaira; allí, unos ańos más tarde, su tranquilidad se alteró con la petición de Manuela España, quien lo reclamó como suyo por ser heredera directa de los bienes de Melchor Carnivel, original amo de Joaquín.

Ante esta contrariedad, Joseph de Jesús se vio forzado a acreditar sus servicios con el fin de frenar las intenciones de Manuela Espańa, a quien no reconoció como ama, y quien, en su opinión, contó con todos los beneficios ante los tribunales. Con este fin le solicitó al señor presidente libertador "se digne en obsequiar de la humanidad de mandar que por este sagrado tribunal sean oídas mis quejas con la verdad que me expreso y sólo su señoría podrá acallar las aflicciones de aquellos y mis aflicciones ordenando se me oiga en providencia por su justicia que imploro". ${ }^{22}$

Con este propósito Joseph reunió las declaraciones juradas de sus superiores Juan José Aguirre, teniente del batallón Orinoco, y del capitán José Lorenzo Jiménez, quienes por su parte aseguraron conocer los servicios de Joaquín los años de 1814, 1821 y 1822, y certificaron que éste fue retirado del ejército debido a su inutilidad por su precaria condición física resultado de su dilatado compromiso con la república en la guerra de independencia.

El defensor de Joseph de Jesús, el procurador municipal Rufino González, convencido de los servicios del esclavo en el ejército de libertadores, reclamó el cumplimiento de la resolución general del congreso de Colombia con fecha de 14 de octubre de 1821, la cual

${ }^{22}$ Ibidem, folio 4. 
reconoció la admisión de todos los esclavos que quisieran ejercer el oficio de las armas, y que los amos de éstos fueran indemnizados con preferencia de los fondos de manumisión que se llegasen a recolectar. De esta forma, solicitó al gobierno que el esclavo sea comprendido en esta resolución, y que los amos sean enterados de su causa y se les cancele el precio de la libertad que había logrado meritoriamente.

Enterado de la causa, el yerno y apoderado de Manuela Espańa, José de Arizabalo, se presentó ante el tribunal con el oficio original de compra-venta del esclavo hecha por el difunto Carnivel con fecha de enero 25 de 1813. En éste constó que un tal don Esteban Escobar le vendió a don Melchor el esclavo Joseph de Jesús por 300 pesos después que este último se fugó de su hogar para refugiarse en casa de Carnivel. Después de esta certificación de propiedad, expresó que evidentemente el esclavo demostró con éxito sus servicios como consta en las declaraciones de sus superiores y, por lo tanto, ni él ni la seńora Manuela estaban dispuestos a contrariar el alcance de dicha gracia.

No obstante, aseguró, que de igual manera como el tribunal estaba procurando la libertad del siervo, también debía cumplir con indemnizar de manera satisfactoria a los dueños, de lo contrario se estaría violando de manera flagrante el artículo 177 de la constitución de la República de Colombia, el cual sancionaba que ningún ciudadano podía ser privado del uso de su propiedad aunque sean empleados en usos públicos sin su consentimiento. ${ }^{23}$ Pero en el caso de que existiere alguna necesidad pública comprobada legalmente en el uso de dicho bien se presuponía la justa compensación por parte del Estado.

Por lo tanto, Arizabalo solicitó que antes que se le otorgara carta de libertad a Joseph de Jesús, primero éste debía ser examinado por un perito que las partes acordasen para que realizara un justiprecio, es decir, el otorgamiento de un valor al siervo partiendo de las con-

23 “Constitución de Cúcuta, 1821", Jose Gil Fortoul, Historia Constitucional de Venezuela (Apéndice), t. II, Caracas, Ministerio de Educación, Dirección de Cultura y Bellas Artes, 1954, 587. 
diciones físicas que poseía. Con esta evaluación Manuela de España podía solicitar de los fondos de manumisión de La Villa de la Guaira la indemnización por el esclavo, el cual estimaba debía alcanzar el precio más alto: 300 pesos.

La buena voluntad, colaboración y disposición mostrados hasta ese momento por el representante de Manuela Espańa, desaparecieron una vez que el esclavo prolongó la entrega de copia de la orden de su retiro del ejército, lo que retrasó el fallo del tribunal. Días más tarde se dirigió al tribunal y al procurador defensor de Joseph de Jesús para denunciar que dicho retraso se debió a que no existía ninguna copia, pues el esclavo nunca cumplió con este requisito, además se atrevió a asegurar que ni existía su filiación, pues sus servicios fueron hechos en un corto periodo de tiempo. Por lo tanto, el esclavo viéndose beneficiado de los trastornos y vicisitudes propios de la guerra intentó aprovecharse del beneficio que se le otorgaba a los esclavos que sirvieron a la república durante un amplio espacio de tiempo, y que además se encontraban aún en servicio.

José de Arizabalo concluyó su denuncia afirmando que el Estado no debió pagar el valor de este falso y malicioso esclavo por tan poco tiempo en servicio, pues, la separación voluntaria del ejército y su posterior regreso a la casa de Manuela significó que éste renunció a la manumisión que dijo merecer. Finalmente, pidió que Joseph de Jesús sea restituido a Manuela como su propiedad para que cancelara los jornales diarios que debía desde el momento que se fue a trabajar en el puerto de La Guaira como caletero sin su consentimiento, aconsejó a los señores alcaldes del puerto de La Guaira que se aprese a este individuo pues su antigua tacha o reputación de prófugo lo obligará a eludir el regreso a casa de su ama.

El procurador, al enterarse de la petición, respondió a las consideraciones hechas por el representante de la señora Manuela: "La cárcel, Señor, esta destinada para los criminales. Un esclavo no lo es por solo ser de esta condición". ${ }^{24}$ Continuó el procurador diciendo que aunque Joseph de Jesús tuvo la tacha de prófugo no es razón suficiente para su encarcelamiento, tampoco entiende la contradic-

${ }^{24}$ Ibidem, folio 14. 
ción en la que cayó Arizabalo quien se empeñó en catalogar al siervo de cimarrón y al mismo tiempo pide 300 pesos al Estado por su valor. ${ }^{25}$ Aseguró que efectivamente el esclavo le confesó que no posee consigo las letras de retiro y filiación que se le solicitaron, no obstante, consideró que su ausencia no destruye el derecho con que aspira a su libertad. Sus servicios en los años de 1814, 1820 y 1821 estuvieron comprobados por medio de la declaración de sus superiores, años que -en palabras del procurador-fueron las épocas más arriesgadas e importantes de la República. Dijo desconocer un código que expresara tácitamente los decretos emitidos por Bolívar, pero éstos están mezclados con los primeros delineamientos de la infancia de la Repúbli$c a$, y que se encuentran ratificados a través de la resolución del congreso del 14 de octubre de 1825 .

Concluyó, después de considerar justa la indemnización de doña Manuela, que es cierto que:

Malpica no ha obtenido su retiro, no sirve en ningún batallón, pero pertenece al gremio de caleteros, que es la primera muralla de La Guaira, pero ha servido largo tiempo a la patria, que es la sustancia; y por ello es acreedor de su libertad. Volviendo a la casa de su señora, el no ha renunciado como se pretende, a este derecho; por que no ha podido renunciar a la cualidad de hombre. Un derecho tan importante no se pierde ni aún por un convenio expreso: porque es esencialmente nulo. ${ }^{26}$

El tribunal sin mayor retraso del proceso le otorgó la libertad a Joseph de Jesús Malpica por su dilatado servicio al ejército republicano, su ama fue indemnizada por la junta de manumisión de su cantón después que realizó el justiprecio del esclavo, que dońa Manuela consideró debieron ser 300 pesos por la edad del esclavo que era de 31 años.

Como Joseph de Jesús, los esclavos involucrados en la guerra eran en su mayoría criollos nacidos en la provincia, pero existieron casos excepcionales como el de Joaquín Vivas, quien nacido en libertad en

${ }^{25}$ Un esclavo con tacha de prófugo disminuía su valor al momento de una posible venta, inclusive si éste se encontraba en plena edad productiva.

${ }^{26}$ Ibidem, folio 14 vto. 
África fue arrastrado a los insalubres depósitos de los barcos negreros para ser trasladado a una América dividida y en cruenta guerra.

\section{De ESClavo BozAl a SOLDADO REPUBLICANO}

La motivación que llevó al esclavo Joaquín Vivas ante la presencia del procurador de La Guaira un 13 de mayo de 1830 fue el temor de ser vendido por sexta vez en menos de 16 años. Para ese momento tenía 30 años de edad, ya había vivido y recorrido lo suficiente, por lo tanto era un buen momento para certificar sus servicios en el ejército republicano a fin de lograr la carta de libertad que impediría la tutela de un nuevo amo.

Antes de 1811, Joaquín Vivas sobrevivió a corta edad el cruel camino medio que lo trasladó de su Guinea natal al puerto de $\mathrm{La}$ Guaira. Se desconoce el número de puertos que transitó antes de llegar a esta provincia. Según testimonios posteriores fue comprado por 280 pesos por un vecino de La Guaira llamado Juan Antonio Vivas, quien siguió la vieja costumbre le colocó un nombre cristiano y su apellido como emblema de padrinaje y propiedad.

Al transcurrir un par de años, y mientras se empezaron a reflejar con más fuerza los rigores de la guerra de independencia en la población, la esposa de Vivas -Candelaria Acosta de Vivas- decidió vender a Joaquín, porque no manejaba aún un oficio definido y se le complicaba costear su sustento. El comprador inmediato fue Feliciano Jiménez y el año de la venta 1814. La Guaira para ese momento era zona transitada por tropas patriotas que arribaban apresuradamente con el propósito de dirigirse a los valles occidentales para contrarrestar el devastador avance de las tropas realistas. Dichos esfuerzos fueron en vano, el 15 de junio de 1814, Bolívar se replegó en dirección hacia Caracas tras su derrota en La Puerta.

El acercamiento del general Boves a la capital fue inminente, y el intento de los patriotas de mantener la república resultó infructuoso, frente a este escenario la temerosa población huyó en dirección a Oriente, entre la nerviosa multitud de esa mañana del 7 de julio de 1814 iba la familia Jiménez escoltada por Joaquín quien llevó como único equipaje una petaca sostenida sobre su cabeza. 
Fueron 23 días de caminata signados por el hambre, la intemperie y la muerte. Del número estimado de 20 mil personas que partieron esa tarde de julio, llegaron con vida a Barcelona sólo 9 mil. El matrimonio Jiménez y Joaquín se contó entre los sobrevivientes; empero, la salud de la esposa de don Feliciano era precaria, durante el recorrido contrajo la enfermedad de la muerte.

La delicada condición de salud de su esposa no impidió que Feliciano Jiménez se pusiera a las órdenes del ejército republicano en el cuartel general de la ciudad de Barcelona, como también lo hizo con Joaquín, quien pasó en calidad de soldado a la compañía de zapadores comandada por el general Manuel Piar. De allí, ambos se desplazaron a Villa de Aragua de Barcelona para formar parte de los 2 mil soldados que defendieron esta plaza de la arremetida de los 5 mil combatientes capitaneados por Francisco Tomás Morales. El enfrentamiento se inició a tempranas horas de la mañana y se prolongó por 7 horas que finalizaron con la derrota republicana, Feliciano Jiménez falleció en combate y Joaquín emprendió la retirada herido por un proyectil que se alojó en su muslo izquierdo, bala que él mismo retiró posteriormente por medio de procedimientos caseros.

A pesar del primer fracaso y de la muerte de su amo, continuó sirviendo a la república en Cumaná, donde fue incorporado en el escuadrón de caballería que mandaba el capitán Hilario Carrasco. ${ }^{27}$ Sirvió tres meses en ese escuadrón, participó en dos encuentros hasta principios del mes de octubre de 1814, cuando José Tomás Boves tomó con violencia aquella ciudad, lo que lo obligó de nuevo a huir.

Joaquín regresó con su ama, la viuda de Feliciano Jiménez, quien entonces residía en casa de José Antonio Rojas, vecino de la ciudad de Barcelona quien le brindó asistencia y alimentos durante la convalecencia de la fatal enfermedad que adquirió en su recorrido hasta oriente. A poco de la llegada de Joaquín, María del Sacramento Ortega falleció luego que ningún medicamento pudo sanar los padecimientos acentuados por su reciente estado de viudez.

27 “El Síndico Procurador General por el esclavo Joaquín Vivas solicita lo declaren libre por haber servido al ejército de la República”. Caracas, 1830, Academia Nacional de la Historia, 1830 LPV, exp. 4. 
Joaquín después de este trágico evento quedó sirviendo en casa de Rojas, como lo explicó posteriormente el mismo siervo: "para que de mi trabajo se pagase la curación y alimentos que había prestado a mi enunciada ama durante su enfermedad" ${ }^{28}$ No obstante, poco fueron los jornales que prestó Joaquín, ya que Rojas carecía de documentos de propiedad que lo identificasen como su amo, simultáneamente, el acercamiento de las tropas patriotas a la ciudad provocó una nueva desbandada de la población allí residente, entre ellos Joaquín.

Mientras el movimiento patriota se desvaneció en las disputas de sus principales generales, Joaquín, acompañado de otro soldado llamado Reyes Laya, retornó al puerto de La Guaira después de tres años de ausencia. Allí se dedicó al oficio de caletero, con el infortunio que en uno de esos días de labores fue reconocido por un compadre de su ama inicial - Candelaria Acosta de Vivas- quien lo colocó de nuevo a su servicio, Joaquín no puso ninguna resistencia a esta determinación, el solo hecho de alegar la libertad que consideraba había obtenido por el servicio prestado a las armas republicanas le pudo costar posible pena capital, recordemos que desde mediados de 1814 , la capital y el puerto yacían bajo dominio realista.

Transcurrieron 10 años, dentro de los cuales los republicanos aseguraron su definitiva victoria, y aún así Joaquín no llegó a acreditar sus servicios ni cuestionó su nuevo estado de servidumbre, inclusive cuando su antigua ama lo vendió de nuevo por 100 pesos al sr. Juan Boza desconoció su carrera militar. Sin embargo, cuando surgió otra intención de venta a principios de 1830, Joaquín se dirigió al procurador general de la villa para hacer constar sus servicios y lograr la libertad que se encontraba asentada en decretos republicanos desde 1816.

Mientras el tribunal solicitaba los testimonios de los soldados y capitanes que daban fe de la militancia de Joaquín, Juan Boza -el dueño del esclavo para el momento de la querella- obstaculizó al siervo agenciar su libertad al prohibirle abandonar sus ocupaciones hasta que cancelara los tres reales de jornal diarios que le correspon-

${ }^{28}$ Ibidem, folio 1. 
dían. El procurador, el defensor y representante de los esclavos en pleitos judiciales, enteró de esta situación al tribunal, el cual determinó que Joaquín debía cumplir con sus jornales y comprometerse en no tratar de huir mientras el procedimiento estuviese abierto. Joaquín replicó que nunca dio motivos a su amo para que éste sospechase su huida. Con respecto al pago de los jornales diarios, el esclavo señalaba que era injusto, no obstante, colocaba como fiadora a Juana Malpica, vendedora de la plaza, que se encargaría de pagar el dinero cuando él no se encontrase en condiciones de hacerlo. A pesar de que el dominio sobre Joaquín estaba por ser comprobado, estos arreglos del tribunal intentaron proteger los derechos de propiedad del señor Boza.

El juicio continuó y una de las primeras en declarar fue Candelaria Acosta de Vivas, la dos veces dueña de Joaquín, quien desde un principio dudó de los servicios prestados por el bozal a la república, ella aseguraba que para 1814 el esclavo tenía 7 años de edad lo que le impedía ser enlistado, además cuando éste se une a la emigración la venta aún no había terminado de ser cancelada, pues ésta sería pagada por medio de dos reales mensuales que el bozal obtendría de su trabajo con el seńor Feliciano, trato que evidentemente se interrumpió con la partida de la familia Jiménez. Por esta razón, cuando se entera del retorno de Joaquín al puerto de La Guaira en 1817 -después de la advertencia hecha por su compadre Santiago Torrealba- ella reconoció al siervo como parte de su propiedad, y en vista que éste no demostró ninguna oposición a esta determinación ella dispuso de él, y un año mas tarde lo vendió por 100 pesos a Sebastiana Sosa.

Las afirmaciones hechas por la señora Candelaria fueron desestimadas por los seis testigos presentados por Joaquín, quienes atestiguaron la suficiente edad del bozal cuando éste se incorporó al servicio, entre esos testigos estaban, tanto respetables oficiales republicanos, como familiares del difunto matrimonio Jiménez. Además, las contradicciones en su declaración evidenciaron la indebida apropiación de Joaquín, como aquel que aseguraba que había comprado en 1811 o 1812 al muleque de cinco años por 280, cuando en la realidad ese precio sólo lo alcanzaba un joven de 13 años, pasando por alto el principio reconocido que la improductividad de 
un niño esclavo disminuía su valor en comparación con aquellos que tenían entre 15 y 39 años.

El procurador, confiado de las positivas declaraciones y de la inconsistente defensa de la señora Candelaria, pidió consulta a los tesoreros administradores de la aduana, no para que decidan la suerte de Joaquín, porque en su opinión su libertad era un asunto evidente fuera de total discusión y asunto privativo del corregidor cantonal, sino para que se determinase qué dueño merece la cancelación de la manumisión de Joaquín, pues ante las numerosa sucesión de dueños y las turbias formas de adquisición era difícil definir un beneficiario en particular. Los tesoreros después de revisar el expediente expusieron que Joaquín, sin lugar a dudas, es meritorio de carta de libertad, no sólo por los testimonios brindados, sino también por la sangre que derramó en combate tal y como lo comprobó la revisión hecha por el cirujano solicitada por anuencia del corregidor.

Ahora bien, para ellos el asunto era determinar quién debía pagar el valor de la manumisión de Joaquín. Ellos consideraron que el Estado no debía cargar con dicha deuda, pues los verdaderos dueńos de Joaquín se encontraban muertos, y no quienes, posterior a la fecha de este desafortunado suceso, se decían dueños del siervo. Específicamente la señora Candelaria quien "ocultó maliciosamente la edad del siervo y la venta que de él hizo Jiménez, para cubrir el fraude cometido venderlo lo que había vendido a éstos, o mas bien dicho, lo que no era suyo". ${ }^{29}$ Ellos consideraron que los Jiménez al no tener herederos, es decir, nadie que reclamara a Joaquín, éste quedaba libre, no obstante, el astuto proceder de Candelaria lo impidió.

En cuanto a los dos últimos dueños de Joaquín -Sebastián Acosta y Juana de Dios Acosta- los tesoreros explicaron que "debieron antes de comprarlo examinar la legitima propiedad [...] y pues no lo hicieron, piérdase el dinero que dieran por él". ${ }^{30}$ En caso contrario, la opinión era que de los bienes de Candelaria Acosta se hiciese la indemnización a los incautos compradores. Pero durante la realización de este proceso, doña Candelaria huyó a Cariaco. Las

${ }^{29}$ Ibidem, folio 18 .

${ }^{30}$ Idem. 
autoridades, por su parte, enviaron un comunicado hasta aquella lejana provincia donde la hallaron, a ella no le quedó más remedio que admitir su estado de pobreza y su incapacidad para responder a cualquier sentencia que implicara enmendar económicamente la venta indebida del esclavo que ya no le pertenecía.

Lamentablemente hasta aquí llega el rastro de Joaquín, el expediente se encuentra incompleto impidiéndonos saber el desenlace de su solicitud. Ante este obstáculo sólo nos queda hacer un comentario sobre la sentencia, inferimos que Joaquín pudo obtener su declaratoria de libertad después de un largo y tortuoso periplo, esto lo desprendemos del comportamiento ya apreciado en las solicitudes anteriores, que siempre contaron al inicio con cierto grado de oposición por parte de las autoridades, pero que posteriormente después de prolongados padecimientos culminaba con el otorgamiento de carta de libertad.

\section{LA MUERTE ANTES QUE REGRESAR A LA ESCLAVITUD}

En la historiografía independentista la presencia femenina ha sido escasa, más si se refiere a esclavas. A pesar de que no fueron agentes bélicos activos, si estuvieron presentes como enfermeras improvisadas o como las esposas de soldados que seguían el paso de las tropas en sus interminables marchas. Ese fue el caso de Petrona Cardozo, quien en compañía de su hija Andrea, partió del atribulado poblado de Calabozo al resguardo de las tropas patriotas en una fecha imprecisa, en la marcha Petrona contrajo nupcias con un esclavo llamado Domingo Gutiérrez que para el momento era soldado activo del ejército patriota y se residenció en la Guayana patriota de 1817. Estas últimas acciones de Andrea fueron las primeras que realizó como mujer libre, pues ellas habían quedado libres de servidumbre desde 1818, cuando Bolívar dispuso que todos los esclavos habitantes de Guayana, Barinas y Apure, se convirtieran en ciudadanos sin condición ni distinción alguna. Desde ese momento Petrona, en sus propias palabras: "he sido considerada, habida, tenida y respetada como persona libre, como si lo hubiera sido desde mi nacimiento, en virtud de los decretos expedidos por el presidente libertador, y 
por el actual presidente del estado, favoreciendo y amparando la clase miserable sujeta a servidumbre, que fieles a la causa de la libertad manifestaron su adhesión a ella impregnados del más acendrado patriotismo". ${ }^{31}$

Años más tarde, en 1833, mientras la familia se encontraba residenciada en el poblado de Achaguas, Juan López y Juana Letras, antiguos amos de Petrona y Andrea, reaparecieron solicitándolas como parte de sus propiedades, desconociendo así su condición de libres y cualquier decreto que certificara esa postura. Domingo Gutiérrez sale en defensa de su esposa e inicia un proceso judicial ante el alcalde municipal de Achaguas quien sentenció a favor de los amos, pues caso contrario al de Gutiérrez que militó en el ejército, desconoció decreto alguno que le otorgara la libertad a esclavos que no tomaron las armas, por ello éstas deben retornar inmediatamente a la ciudad de Calabozo con sus dueños. Éste no era un escenario inusual, los propietarios de esclavos, emplearon la dilación y obstrucción para disminuir el impacto de las distintas proclamas promulgadas en tiempo de guerra. Muchas veces esa obstrucción contó con el auspicio de autoridades regionales, que desconocieron estas disposiciones, indistintamente por ignorancia o interesada omisión con el fin de beneficiar a los hacendados. Ante esta determinación Cardozo y Gutiérrez no se detuvieron y llevaron su causa al gobierno superior de la provincia de Apure, el gobernador frente a este dilema le comunicó a las esclavas que su petición posee meritos suficientes para ser presentada a la Corte Superior de Justicia pues el consideraba que no contó con la potestad de revisar la sentencia de ese tribunal. Entonces así se hizo, expusieron su caso con claridad por dos ańos sin respuesta, reiterando "que las ofertas hechas por el gobierno en las circunstancias las más críticas, sean religiosamente cumplidas [...] para que se me ampare en el goce de la libertad, por consecuencias de ellas". ${ }^{32}$

Ella aseguró que la decisión que tomó este alto tribunal con su caso, tuvo grandes repercusiones en muchas personas que se encon-

${ }^{31}$ Archivo General de la Nación, Secretaria de Interior y Justicia, t. LXvI, exp. 11, $1833,291$.

${ }^{32}$ Ibidem, p. 194. 
traban en su misma condición, y en el caso de ser improcedente, su despacho se vio inundado de demandas similares a la de ella

Parece excelentísimo Sr. que la libertad concedida a los esclavos que se encontraron en esta provincia en la época que se publicaron dichas disposiciones no debe ser alterada en manera alguna y mucho menos discutida por los tribunales superiores; creo que en el desgraciado caso de que fueren derogadas corresponde tal declaratoria a otra autoridad superior; lo que ciertamente causaría muchos trastornos y disgustos respecto a que hay infinitos que se hallan en igual caso, casadas con oficiales del ejercito libertador que en el seguro concepto de que se hallaban en el goce de su libertad no tuvieron duda en contraer sus matrimonios. ${ }^{33}$

Mientras los años transcurrieron sin respuesta del alto tribunal, Andrea y Petrona por el temor de ser llevadas a la fuerza a la ciudad de Calabozo por el encargado de sus amos Miguel Pitaluga, no salieron de su hogar lo que les impidió procurarse el sustento. En medio de la incertidumbre, solicitaron a sus amos papel de venta pues no querían regresar con ellos, y en su lugar prefirió servir al coronel Facundo Mirabal y su esposa la señora Bárbara Mirabal quienes estuvieron dispuestos a comprarlas por el valor que ellos determinasen. Sus amos aceptaron, pero con una condición, una de ellas debía regresar a Calabozo, Andrea al escuchar esta decisión sacó un cuchillo que ha prevención llevaba consigo e intentó darse de puñaladas, acción que impidió la Sra. Bárbara, Andrea aseguraba que prefería la muerte que regresar al estado de servidumbre.

El encargado de llevárselas al ver el giro dramático de la situación, les concedió más tiempo para que esperasen las resultas de la Corte Superior de Justicia. La respuesta llegó publicada en Gaceta Oficial, gracias a la intervención del gobernador de Apure, quien preguntó si las proclamas del general Bolívar se hallaban en su fuerza y vigor de ley, porque la Ley de Manumisión de 1830 derogó todas las leyes anteriores a su puesta en vigencia, a lo que respondió la Secretaria de Interior y Justicia con extrema dureza, que la decisión

${ }^{33}$ Idem. 
era ilegal, por demás inconcebible al utilizar como respaldo la Ley de Manumisión de 1830, señalando "Son perpetua e irrevocablemente libres todos los individuos, que en virtud de las leyes y decretos del Gobierno de la República, han salido de la esclavitud en sus distintas épocas, por efecto de dichas disposiciones". ${ }^{34}$

Apuntó por demás que los jueces cometieron una arbitrariedad y una infracción a la ley "perniciosa al orden público y tan ofensiva a la justicia”. ${ }^{35}$ Sin más dilaciones Andrea y Petrona Cardozo eran por segunda vez libres, frente a la frustración y perplejidad de muchos propietarios de esclavos de esta región, quienes consideraron inconstitucionales esas disposiciones que debieron morir con la disolución de la Gran Colombia. Sus quejas eran valederas, Bolívar ofreció libertad a lo largo del territorio nacional, y aun así el sistema continuó vigente, ejemplo de ello la provincia de Caracas. Ellos se quejaron del trato diferente, y no se explicaron por qué en su provincia éstas debían ser estrictamente cumplidas. El Estado terminó imponiéndose, y Guayana para la década de 1840 no tenía casi esclavos. ${ }^{36}$

Se puede interpretar de varias maneras dicho punto de vista, como Guayana poseyó una pequeña cantidad de esclavos en comparación con las provincias de las costa, resultó más fácil al gobierno imponer ese propósito de extinguir paulatinamente la esclavitud. También las contradicciones ideológicas tomaron más fuerza, e indistintamente de que el gobierno fuese conservador o liberal, ninguno quiso que las inconformidades de los negros fueran capitalizadas por banderas políticas, amenazando así el orden público.

\section{Consideraciones finales}

Con el inicio de la guerra de independencia, los bandos en pugna querían favorecerse de la fortaleza y resistencia de los esclavos y para lograrlo se les ofreció la libertad a cambio de la toma indefinida de las armas. Aquellos que atendieron este llamado abandonaron a sus

${ }^{34}$ Gaceta de Venezuela, Caracas, número 221, sábado 4 de abril de 1835.

${ }^{35}$ Idem.

${ }^{36}$ John Lombardi, Decadencia y abolición de la esclavitud en Venezuela 1820-1854, p. 92. 
familias, recorrieron miles de kilómetros a tierras desconocidas, fueron heridos en batalla y mataron con el propósito de ser merecedores de la gracia que les ofrecía indistintamente un rey ausente o una república por consolidar. Usualmente, los esclavos acreditaban sus servicios militares años después de haberlos prestado, principalmente cuando se veían en la necesidad de frenar las intenciones de sus antiguos amos, quienes pretendían regresarlos forzosamente a sus dominios. Éste fue el principal motor de las peticiones aquí presentadas.

Algunos esclavos, asediados por el enemigo, regresaron al poder de sus amos interrumpiendo así su servicio, años más tarde intentarían demostrarlos ante los tribunales competentes frente a la obstinada oposición de sus amos. Otros que sí se mantuvieron en la guerra y se salvaron tomaron por hecho su condición de hombres libres, pero la aparición y posterior reclamo de sus antiguos amos interrumpieron el goce pleno de sus libertades obligándoles a demostrar sus servicios a la causa patriota.

Rememoraron, entonces, ante los jueces de sus localidades, cada una de las contiendas en las que participaron, tocaron las puertas de sus antiguos superiores pidiendo certificaciones, mostraron sus cuerpos desnudos a protomédicos para que reconocieran las cicatrices de las balas disparadas en el campo de batalla que atravesaron sus músculos.

Se desconoce la cantidad de esclavos que sirvieron a lo largo del conflicto independentista, se deduce que la libertad por medio del servicio de las armas contó con pocos beneficiarios. Antonieta Camacho en su trabajo introductorio para Materiales para el estudio de la cuestión agraria (1810-1865) afirma que para el periodo 18211827, sólo 41 esclavos fueron liberados por esta modalidad. ${ }^{37}$ Pero aportar un número exacto es arduo, primeramente, las mismas características del conflicto durante los primeros años hicieron de la conscripción de esclavos un proceso azaroso donde el formalismo jurídico era una cuestión de lujo. Igualmente, la militancia esclava

${ }^{37}$ Antonia Camacho S., "Aportes para el estudio de la formación de la mano de obra en Venezuela: Esclavos y libres (1810-1865)”. Introducción a Materiales para el estudio de la cuestión agraria (1810-1865), Caracas, Ediciones de la Facultad de la Humanidades y Educación, vol. I, pp. vII-XLVII, 1979, 736. 
era volátil, un día un mismo esclavo podía matar por Fernando VII en las tropas del realista Francisco Tomas Morales y pocos meses después podía estar entregando la vida a la causa republicana, mejor ejemplo de ello fue el esclavo y prócer Pedro Camejo, mejor conocido como el Negro Primero quien en su primera adhesión a la causa del rey fue la obtención de un uniforme. Frente a las características de esta población es difícil determinar entonces su participación en términos cuantitativos exactos, no obstante, lo que si nos aportan estas fuentes disponibles y aun inexploradas es la comprensión del sistema esclavista durante la emancipación a partir del testimonio de sus propios protagonistas

A medida que la contienda bélica disminuía su intensidad, y la victoria se inclinaba hacia los republicanos, las proclamas que una vez se hicieron por las necesidades de la guerra fueron reevaluadas y orientadas en fórmulas mucho más conservadoras que pretendían prolongar el sistema esclavista, especialmente después de disuelta la república de Colombia (1819-1820). Por ello, el 25 de junio de 1835, la Secretaría del Interior y Justicia de la República de Venezuela emitió el decreto Quedan esclavos los esclavos que abrasen el servicio militar, ${ }^{38}$ los esclavos en consecuencia ya no podían ingresar al servicio de las armas, ni mucho menos obtener la libertad por este medio. La razón de esta decisión: el perjuicio que le provocaban a sus señores algunos esclavos que con poco tiempo en el servicio se identificaban como libres provocando desorden en sus familias y en las haciendas, convirtiendo de esta manera a los cuarteles en asilo de siervos delincuentes. Con esto se ponía fin al mecanismo de obtención de libertad por la carrera de las armas vigente por casi 20 ańos.

El funcionario signatario de este decreto es Antonio Leocadio Guzmán, quien dos años antes se había dirigido al juez letrado de la provincia de Caracas a reclamar la indemnización de dos esclavos suyos -Antonio Arias y Pedro Guzmán- que se hallaban sirviendo en el batallón Apure desde 1822 mientras él se encontraba en el exterior. Por ambos recibió 600 pesos, después de un rápido y poco

${ }^{38}$ Ibidem, vol. I, pp. 142-143. 
detallado procedimiento de avalúo. ${ }^{39}$ Paradójicamente, el mismo Antonio Leocadio Guzmán después fue fundador del partido liberal venezolano, facción conocida tradicionalmente por la historiografía como la defensora de la abolición de la esclavitud.

Finalizada la conscripción esclava, los propietarios intentaron recuperar aunque fuese un menor porcentaje de sus fortunas menguadas por la guerra, e iniciaron con este fin el reestablecimiento del sistema esclavista. Efectivamente, éste no era el mismo, era complicado que todos los esclavos volviesen a sus antiguas labores, muchos se desplazaron a otras ciudades como gran parte de la población, y encontraron nuevos hogares y trabajos como hombres libres. Las normativas de manumisión, mayor testigo del fracaso de las intenciones republicanas, prolongaron el sistema unos ańos más, cuando en términos reales no aportaban lo suficiente a la economía nacional. Por medio de esto vemos un fuerte indicio de la permanencia de la conciencia tradicional en tiempos republicanos. Anualmente las denominadas juntas de manumisión no alcanzaron a recaudar el dinero suficiente para manumitir el número de esclavos que se fijó. Por otra parte, la ley de vientres libres benefició a individuos que estaban por nacer o no habían nacido, en un plazo de 18 años para la Gran Colombia, y 21 cuando se fundó el Estado venezolano en 1830. Éste fue el espíritu que prevaleció hasta la mitad del siglo XIX, cuando se tomó conciencia que ya no tenía sentido mantener a un grupo de individuos bajo la sujeción de otros con la promulgación de la ley de abolición del 26 de marzo de 1854.

Finalmente, los esclavos estuvieron en la guerra de forma evidente, vimos individuos que un lustro atrás en sus labores de campo o de casa no se imaginaron recorrer miles de kilómetros a tierras desconocidas como las de Nueva Granada, ni mucho menos la oportunidad de vislumbrar la interacción en calidad de iguales que lograron con hombres que podían ser sus propietarios. Su presencia fue temida, no hay duda; pero este movimiento esclavo no se aventuró más allá de la obtención de la libertad individual. Aunque se

${ }^{39}$ Archivo General de la Nación, Secretaria de Interior y Justicia, tomo xLviII, 1832, exp. 36 . 
hicieron sentir, no contaron con un plan diseñado por ellos mismos, y su participación siempre estuvo dirigida por caudillos que les ofrecieron libertad. No obstante, las historias de estos 6 esclavos nos permitieron conocer un pequeño fragmento de las experiencias a que estos hombres se sometieron y fueron sometidos con el único fin de ser reconocidos como hombres libres. Sus vidas y relatos son excepcionales frente a una mayoría que permaneció en esclavitud o pereció en el campo de batalla.

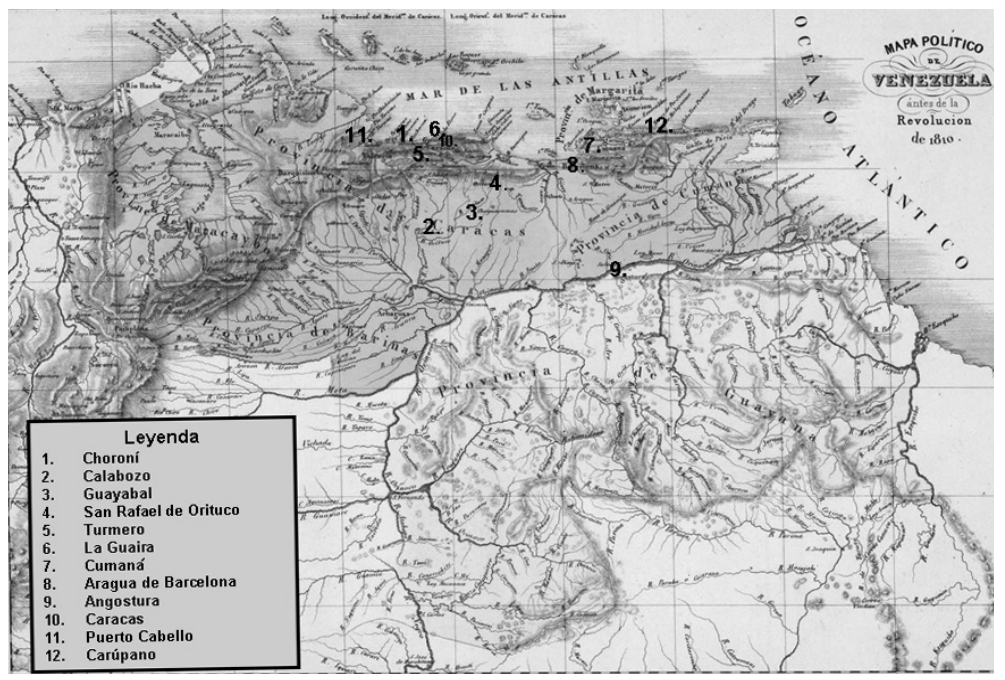

Mapa oficial de Venezuela, Agustín Codazzi, 1840. Leyenda elaborada por la autora.

\section{ArCHIVOS}

Archivo General de la Nación (Venezuela). Archivo General de la Nación, Archivo Aragua.

Academia Nacional de la Historia.

\section{BIBLIOGRAFÍA}

Archivo del General Miranda (Campaña de Venezuela, prisión y muerte del General Miranda: 1811-1816) Documentos oficiales de 
1811 a 1812 y correspondencia de 1812 a 1816, tomo xxIV, La Habana, Editorial Lex, 1950, 573.

Austria, José de, Bosquejo de la historia militar de Venezuela, vol. II, Caracas, Academia Nacional de la Historia, 1960, 448.

Bolívar, Simón, Obras completas, t. viII, México, Editorial Cumbre, 1976, 197.

Camacho S., Antonia, "Aportes para el estudio de la formación de la mano de obra en Venezuela: Esclavos y libres (1810-1865)". Introducción a Materiales para el estudio de la cuestión agraria(1810-1865), Caracas, Ediciones de la Facultad de la Humanidades y Educación, vol. I, pp. vII-XLVII, 1979, 736.

Carrera Damas, German, La crisis de la sociedad colonial, Caracas, Imprenta Municipal, 1976, 101.

Gaceta de Venezuela, Caracas, número 221, sábado 4 de abril de 1835.

Gil Fortoul, José, Historia Constitucional de Venezuela (Apéndice),

t. II, Caracas, Ministerio de Educación, Dirección de Cultura y Bellas Artes, 1954, 587.

HacketT, James y Charles Brown, Narraciones de dos expedicionarios británicos de la independencia, Caracas, Instituto Nacional de Hipódromos, 1966, 62.

Lombardi, John, Decadencia y abolición de la esclavitud en Venezuela 1820-1854, Caracas, Universidad Central de Venezuela, 1974, 92.

Verna, Paul, Petión y Bolivar, Caracas, Ediciones de la Presidencia de la Republica, 1980, 169.

FeCha de RECEPCiÓn DEL ARTículo: 15 de agosto de 2008

FECHA DE ACEPTACIÓN Y RECEPCIÓN DE LA VERSIÓN FINAL: 23 de marzo de 2010 